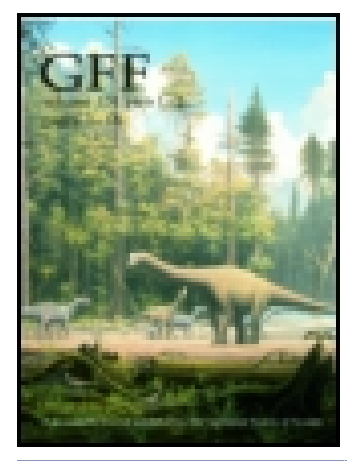

\title{
GFF
}

\section{Siphuncular Structure in the Extant Spirula and in Other Coleoids (Cephalopoda)}

\section{Harry Mutvei}

To cite this article: Harry Mutvei (2016): Siphuncular Structure in the Extant Spirula and in Other Coleoids (Cephalopoda), GFF, DOI: 10.1080/11035897.2016.1227364

To link to this article: http://dx.doi.org/10.1080/11035897.2016.1227364

曲 Published online: 21 Sep 2016.

Submit your article to this journal ๘

Q View related articles $\llbracket$

View Crossmark data ¿ 


\title{
Siphuncular Structure in the Extant Spirula and in Other Coleoids (Cephalopoda)
}

\author{
Harry Mutvei \\ Department of Palaeobiology, Swedish Museum of Natural History, Box 50007, SE-10405 Stockholm, Sweden
}

\begin{abstract}
The shell wall in Spirula is composed of prismatic layers, whereas the septa consist of lamello-fibrillar nacre. The septal neck is holochoanitic and consists of two calcareous layers: the outer lamello-fibrillar nacreous layer that continues from the septum, and the inner pillar layer that covers the inner surface of the septal neck. The pillar layer probably is a structurally modified simple prisma layer that covers the inner surface of the septal neck in Nautilus. The pillars have a complicated crystalline structure and contain high amount of chitinous substance. The interspaces between the pillars probably are traversed horizontally by numerous chitinous membranes like in the cuttlebone chambers in Sepia. The connecting ring is composed of similar two layers as that in the extant Nautilus: the outer spherulitic-prismatic layer and the inner chitinous layer. The spherulitic-prismatic layer takes its origin on the outer surface of the septal neck, whereas the inner chitinous layer is the non-calcified continuation of the lamello-fibrillar nacreous layer of the septal neck. The siphuncular structure in Spirula is compared with that in the extant Nautilus, fossil nautilosiphonate nautiloids, and five taxa of coleoids.
\end{abstract}

\section{ARTICLE HISTORY}

Received 13 May 2016

Accepted 23 June 2016

\section{KEYWORDS}

Siphuncular structures; connecting rings; Spirula; pillar layer; coleoid siphuncles

\section{Introduction}

The connecting ring in cephalopods functions as an osmotic membrane through which the volumes of liquid in the shell chambers are osmotically regulated. The differences in the siphuncular structures indicate different methods of buoyancy regulations, probably caused by different mode of life in different environments.

The siphuncular structure in Spirula has been studied by several writers using the light microscope (Branco 1880; Appellöf 1893; Mutvei 1964). However, detailed structural studies were possible first when the scanning electron microscope (SEM) became available (Dauphin 1976; Bandel \& Boletzky 1979; Bandel 1990; Doguzhaeva 2000; Mutvei \& Donovan 2006). In the latter studies particular attention was paid on the structure of the inner pillar layer of the septal neck. In the present paper, the siphuncular structure in Spirula is described and compared with that in the extant Nautilus and fossil nautilosiphonate nautiloids (Mutvei 2015a, 2016), ammonoids and ammonoids with partially endocochleate shells (Mutvei 2014; Doguzhaeva \& Mutvei 2015), and in four taxa of coleoids: phragmoteuthids (Mutvei \& Donovan 2006), bactritid-like coleoids (Doguzhaeva et al. 1999; Mutvei et al. 2012), belemnitids (Mutvei 2015b) and extant Sepia (Doguzhaeva \& Mutvei 2012; Checa et al. 2015). The mode of life of Spirula is discussed.

\section{Material and Methods}

The material consists of numerous shells of Spirula spirula that were collected on the beaches of the Canary Islands. The siphuncular structure was studied in median sections with a SEM Hitachi S-3400 at the Swedish Museum of Natural History, Stockholm. In order to study the crystalline structure of the siphuncles, the sections were etched with the sodium hypochlorite solution for 2-30 hours. This solution dissolves the chitinous substance between the crystals. The amount and distribution of the chitinous substance were studied by etching the sections of the siphuncles with a solution of 1:1 mixture of $25 \%$ glutaraldehyde and $1 \%$ of acetic acid, to which alcian blue was added, for 1-60 minutes (Mutvei's solution by Schöne et al. 2005). This solution dissolves the crystals and fixes the chitinous substance between them.

\section{Siphuncular Structure in Spirula}

\section{Septal Neck}

The septal neck is long, holochoanitic and extends adapically to the preceding septal neck (Figures 1A, B and 6A, B). Only a narrow interspace is left between the consecutive septal necks. The septa are composed of the lamello-fibrillar nacre (=nacreous type 2 by Mutvei 1970; lamello-fibrillar nacre by Doguzhaeva 2000; lamello-fibrillar structure by Bandel \& Boletzky 1979 and Bandel 1990). The septal neck consists of two calcareous layers: the lamello-fibrillar layer that continues from the septal neck and the pillar layer that covers the inner surface of the septal neck. (Figure 6A; =pillar zone by Bandel \& Boletzky 1979 and Bandel 1990; semi-prismatic layer by Mutvei 1964 and by Dauphin 1976; prismatic layer by Mutvei \& Donovan 2006; spheruliticprismatic layer by Doguzhaeva 2000). The pillar layer consists of 

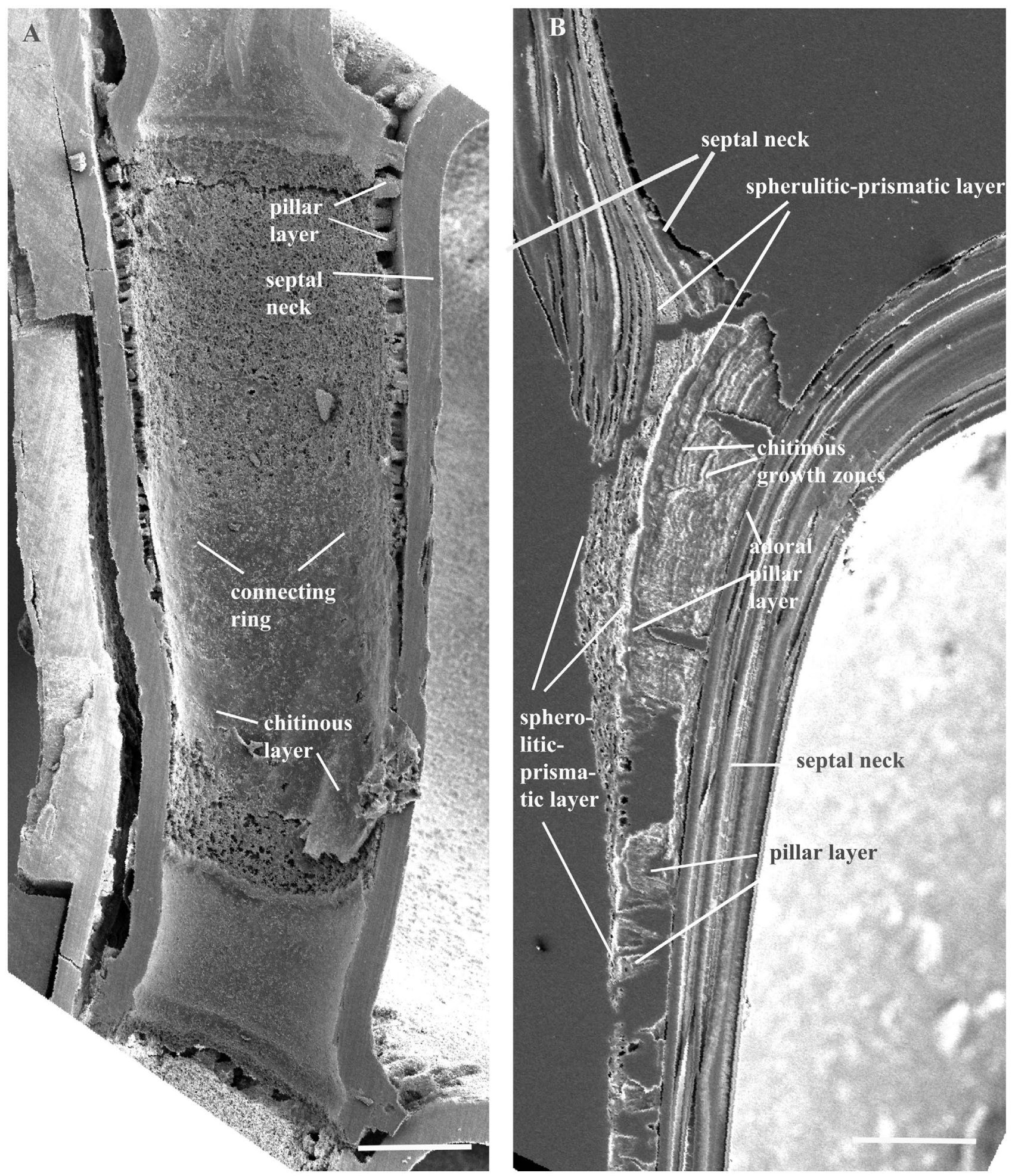

Figure 1. SEM images. Spirula. A. Specimen no. Mo. 180825. Median section of the siphuncle to show a long septal neck that is internally coated by a connecting ring of the succeeding siphuncular segment. Untreated. B. Specimen no. Mo. 180826. Two consecutive septal necks in higher magnification; the inner chitinous layer of the connecting ring is not preserved. Etched for 2 min with Mutvei's solution. Scale bars: $\mathbf{A}=200 \mu \mathrm{m}, \mathbf{B}=100 \mu \mathrm{m}$.

numerous calcareous pillars that are separated by interspaces and oriented at right angles to the siphuncular long axis (Figures 1B and 6D). The layer takes its origin on the adoral surface of the septum, close to the septal neck and covers four-fifth of the inner surface of the septal neck (Figure 6A). In the adoral portion of the septal neck, its thickness is about half of that of the septal neck, but in the adapical direction its thickness gradually decreases and the layer wedges out (Figure 6A, B).

\section{Connecting Ring}

The connecting ring is composed of two layers: the outer spherulitic-prismatic layer, and the inner chitinous layer (Figure 6A, C). The spherulitic-prismatic layer covers the outer surface of the distal portion of the septal neck and continues into the connecting ring (Figure $1 \mathrm{~B}$ and $6 \mathrm{~A}$ ). This layer is thick in the septal neck but decreases rapidly in thickness in adapical 
direction and becomes very thin (Figures $1 \mathrm{~B}$ and 6A; see also Dauphin 1976, Figure 14). It is composed of a layer of spherulitic prisms of irregular shapes without preferred orientation (Figure 2B, C). The inner layer of the connecting ring consists of chitinous membranes. This layer is the non-mineralized continuation of the lamello-fibrillar nacreous layer of the septal neck (Figure 6A, C). The chitinous layer is usually only partially preserved in shells collected on the beaches (Figure 1A).

The two layers of the connecting ring, together with the pillar layer of the preceding septal neck, close the narrow interspace between two consecutive septal necks (Figure 6B). The extension of the pillar layer along the inner surface of the septal neck creates a reservoir and a transportation path for the cameral liquid.

\section{Structure of the Pillar Layer}

In the most adoral region of the pillar layer the pillars are larger than in the rest of the pillar layer, and they are often attached to each other (Figures 1B and 4E). The growth zones of the pillars are often thick and separated by distinct furrows ("terrace-like annulations" Bandel \& Boletzky 1979). The adoral pillars have about 5-15 growth zones (Figures $1 \mathrm{~B}$ and $4 \mathrm{E}$ ). As illustrated by Bandel \& Boletzky (1979, Figure 7A), chitinous membranes from the growth zones traverse the interspaces between the adoral pillars.

In the rest of the pillar layer the pillars are more or less circular in cross-section (Figures 2A and 4A-D). Together with the adoral pillars, they are arranged into numerous rows parallel to the siphuncular long axis (Mutvei 1997, Figure 8A). The adjacent pillars are usually separated by smaller or larger interspaces, but some pillars in a row are in places in contact with each other (Figure 2A). The proximal portion of each pillar is composed of varying numbers of vertical, crystalline columns, mostly $10-20 \mu \mathrm{m}$ in diameter (Figures $2 \mathrm{~A}$ and $3 \mathrm{~B}, \mathrm{C}$ ). The crystalline columns are embedded into a chitinous substance, but their outlines are usually more or less clearly recognizable. The surface of the columns is covered by small crystals that protrude from the interior of the columns through the chitinous substance (Figure 2A). The crystals in the columns are arranged into thin growth zones that are oriented at right angles to the length axis of the columns (Figure 4A, C, D). As counted by Bandel \& Boletzky (1979, p. 324), each pillar has 50-60 growth zones. The distal portions of the vertical columns are transformed into calcareous prisms of various diameters (Figures 2A, 3B and 4A-D). Most prisms are oriented more or less obliquely towards the siphuncular cavity, giving the distal portion of the pillars a blossom-like or an angle-like shape (Figures 2A, B, 3B, D, and 4A-D). In many pillars numerous additional prisms are added to the distal portion. The shape and arrangement of the calcareous components are best visible in the pillars that are treated with the sodium hypochlorite solution that dissolves the chitinous substance (Figures 3C and 4A-D). In order to study the arrangement and amount of the chitinous substance, the pillars were treated with the Mutvei's solution (see above) that fixes the chitinous substance and dissolves the calcareous crystals. The pillars contain a large quantity of chitinous substance that is distributed within the calcareous crystal columns and prisms (Figure 5). Not only the pillar layer, but also the entire shell in Spirula contains high amount of the chitinous substance. This probably modified the crystalline structure of the shell.

\section{Reconstruction of the Pillar Layer}

The Spirula shells described here were exposed at different length of time on beaches before they were collected. It is therefore probable that the chitinous membranes in the siphuncles were more or less destroyed by dissolution and bacterial activity. As pointed out above, Bandel \& Boletzky (1979) illustrated schematically organic membranes that extend in the interspaces between the most adoral pillars. In the rest of the pillar layer no organic membranes were observed. However, it is reasonable to suppose that also here the organic membranes emerged from the growth zones of the pillars and extended in the interspaces between the pillars. In this case the interspaces were traversed by a great number of organic membranes, and the pillars were formed at the places where the membranes become calcified (Figure 6D).

Also in the extant coleoid Sepia numerous, horizontal, chitinous membranes extend between the vertical calcareous pillars in the cuttlebone chambers (Checa et al. 2015). The pillars are formed at the places where the membranes become calcified. In the fossil calciosiphonate nautiloids (Mutvei 2016), the cavities in the calcified perforate layer of the connecting ring probably contained similar chitinous membranes that were destroyed by diagenesis. Also here, the cavity walls probably were formed at places where the membranes became calcified (Mutvei 2016, Figure 9B).

\section{Mode of Life}

In the present seas and oceans, the great majority of squids are diurnal vertical migrants. Because the environment in the oceans and seas still is inadequately known, it is often difficult to understand the function of the vertical migration. Also, Spirula is a diurnal vertical migrant (Bruun 1943; Clarke 1969, 1970; Warnke et al. 2010; Hoffmann \& Warnke 2014). According to Clarke (1969) the entire population lives during daylight at water depths of 600-700 m, but ascends at night to the depths of 100-300 m. Studies of stable isotopes in the shell septa during the ontogeny (Warnke et al. 2010) show that the hatching depth of Spirula is about $800 \mathrm{~m}$. The young animal stays at this depth about 10-14 weeks and migrates then upwards to an average depth of 350$400 \mathrm{~m}$ where it stays the following half year, then descending to an average depth of 550-600 m. According to Clarke (personal communication), the small size of Spirula makes it difficult for the animal to swim against currents. In this case, the animal has to use currents with different directions to maintain its habitat. This was probably also the case with many fossil nautiloids and ammonoids that had inefficient swimming capability.

\section{Comparision with Nautiloids, Ammonoids and Coleoids}

\section{Fossil nautilosiphonate nautiloids and extant Nautilus}

In Nautilus and fossil nautilosiphonates (Mutvei 2015a, 2016) the septal neck is composed of two layers: the outer, columnar nacreous layer and the inner, simple prisma layer (Figure 3A). As described above, also the septal neck in Spirula is composed of two layers, but the outer layer is the lamello-fibrillar nacreous layer, and the inner layer the pillar layer. The pillars are probably structurally modified prisms, and their interspaces are probably traversed by numerous chitinous membranes (Figure 6D). The 

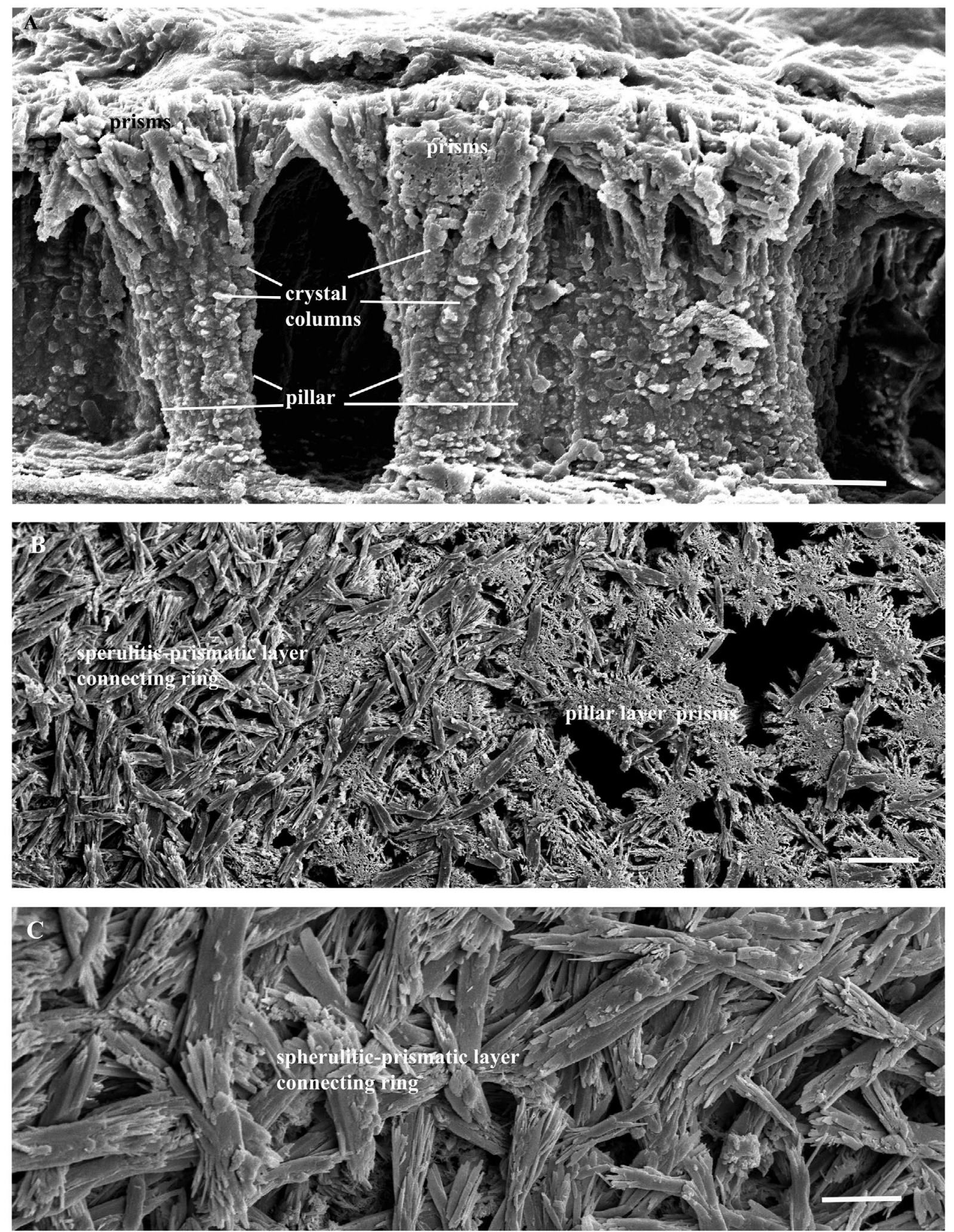

Figure 2. SEM images. Spirula. Specimen no. Mo. 180827. A. Untreated pillars in the pillar layer; note that pillars consist of numerous crystal columns that are transformed distally into prisms. B. Outer surface of the pillar layer; the distal ends of the pillars (right) are covered by a thin spherulitic-prismatic layer (left) of the connecting ring of the succeeding septal neck. $\mathbf{C}$. Outer surface of the spherulitic-prismatic layer of the connecting ring in higher magnification. $S c a l e$ bars: $\mathbf{A}=5 \mu \mathrm{m}, \mathbf{B}=20 \mu \mathrm{m}, \mathbf{C}=10 \mu \mathrm{m}$.

structure of the connecting ring in Spirula shows great similarity to that in Nautilus and nautilosiphonate nautiloids in being composed of the outer spherulitic-prismatic layer and the inner chitinous layer (Figure 6C). This type of the connecting ring does not occur in other, hitherto known coleoids.

\section{Phragmoteuthids (Figure 7C, D)}

According to Mutvei \& Donovan (2006) the septal neck in the Jurassic Phragmoteuthis is orthochoanitic, but it is not known whether it consists of the columnar nacre, as in Nautilus, or of the lamello-fibrillar nacre, as in belemnitids and Spirula. 

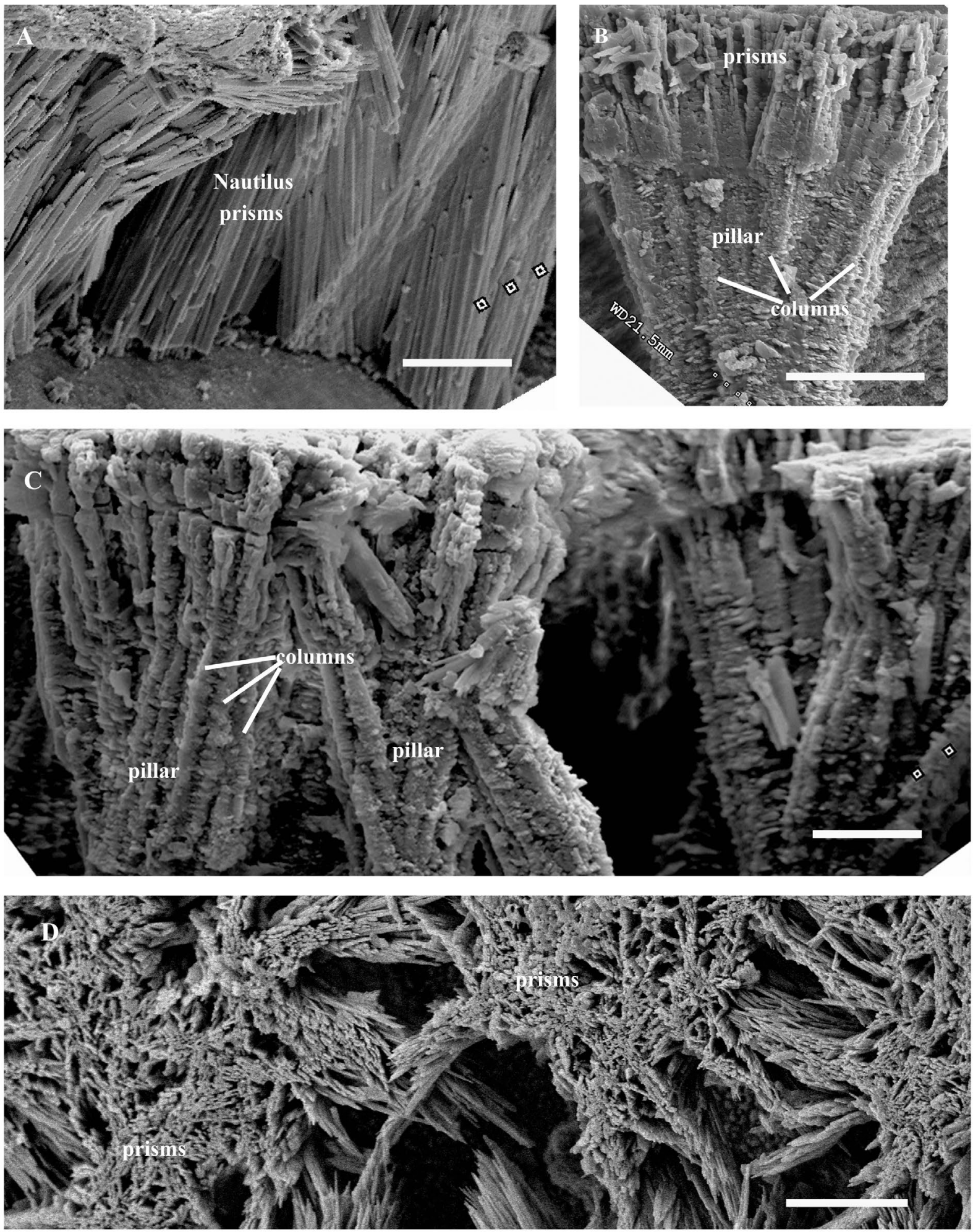

Figure 3. SEM images. Nautilus pompilius. A. Specimen no. Mo. 180823. Prismatic layer on the inner surface of the septal neck; note that this layer has an uncomplicated structure. Untreated. Spirula. B-D. Specimen no. Mo. 180828. B. Distal portion of a pillar to show crystal columns that are distally transformed into prisms. Untreated. C. Pillar layer, treated for $3 \mathrm{~h}$ with the sodium hypochlorite solution, to show numerous columns in each pillar and the arrangement of crystals in the columns. D. Outer surface of the pillar layer to show radiating prisms. Untreated. Scale bars: $\mathbf{A}-\mathbf{C}=10 \mu \mathrm{m}, \mathbf{D}=5 \mu \mathrm{m}$.

Characteristic of Phragmateuthis is the extremely long, calcareous connecting ring that extends through 5-6 chambers (Figure 7C). The permeable siphuncular wall in each chamber therefore consists of 5-6 consecutive connecting rings (Figure 7D). Each connecting ring consists of a single calcareous layer that is composed of prismatic or spherulitic crystallites, and that emerges from the distal end of the septal neck, being a structurally modified continuation of the septal neck. The calcified layer contains cavities of irregular sizes and shapes (Figure 7D). It is not possible to confirm whether these cavities correspond 

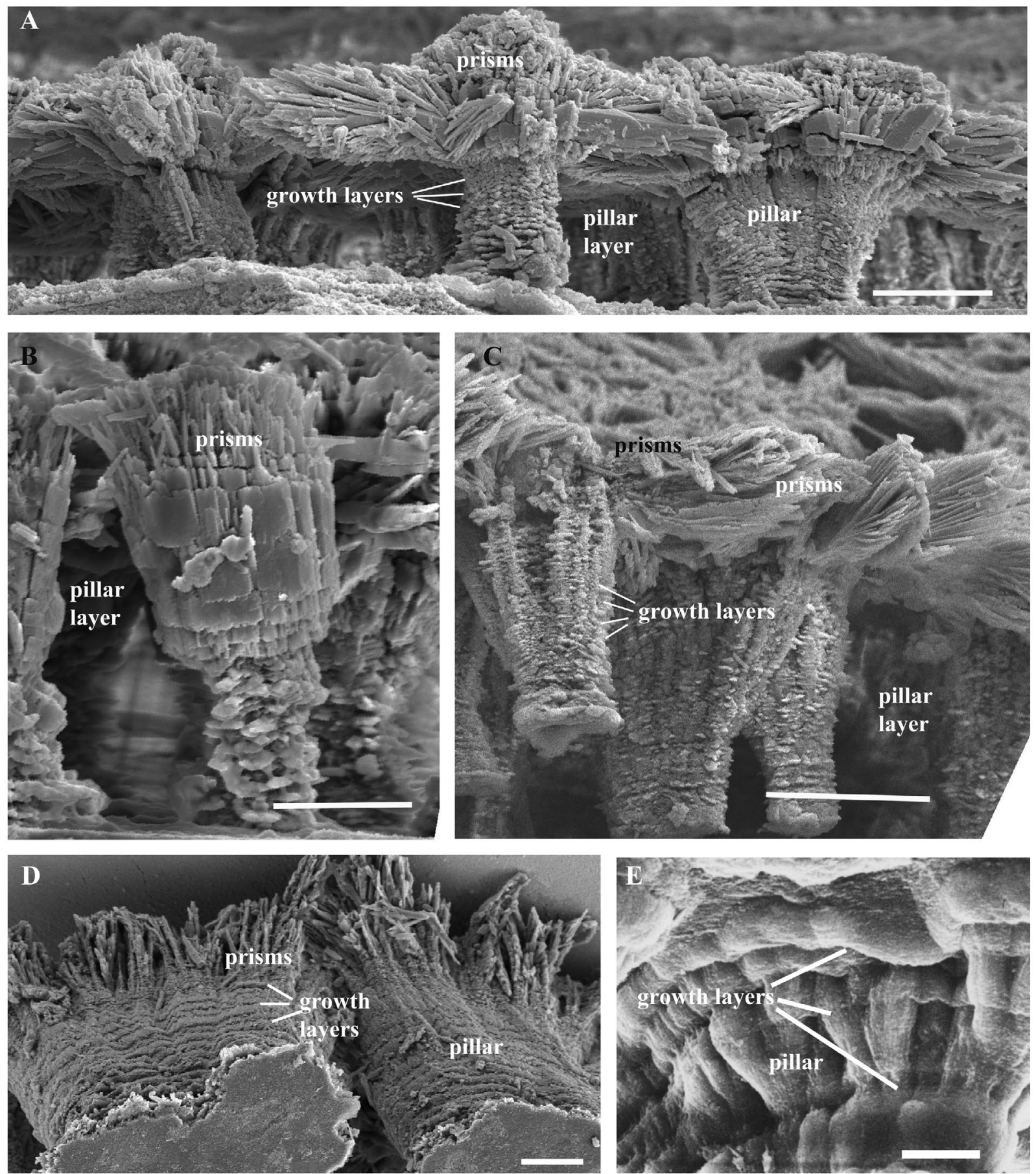

Figure 4. SEM images. Spirula. A-D. Specimen no. Mo.180829. Longitudinal sections of the pillar layer, treated for $4 \mathrm{~h}$ with the sodium hypochlorite solution; note numerous growth layers in the pillars and various arrangements of the distal prisms. E. Specimen no. Mo. 190831. Pillar in adoral part of the pillar layer to show thick growth layers (compare with Fig. 1B). Scale bars: A, C, D, E = $10 \mu \mathrm{m}, \mathbf{B}=5 \mu \mathrm{m}$.

to those in the calcified perforate layer of the connecting ring in the fossil calciosiphonate nautiloids (Mutvei 2016).

\section{Bactritid-like Coleoids (Figure 6G)}

In three taxa designated to Bactritoidea (Mapes 1979, Doguzhaeva et al. 1999; Mutvei et al. 2012) the septa and septal necks consist of the lamello-prismatic layer that differs from the lamellofibrillar nacre in the belemnitids and extant Spirula (Doguzhaeva et al. 2003; Mutvei et al. 2012). In the bactritid taxa, the septal neck is orthochoanitic. The connecting ring is preserved as a single chitinous layer that originates from the lamello-prismatic layer of the septal neck ((Figure 6(G); Doguzhaeva 2000; Mutvei et al. 2012). As in ammonoids and ammonoids with partially endocochleate shells, the connecting ring in the bactrititid-like coleoids lacks the outer spherulitic-prismatic layer (Figure 6(G)). In both taxa the chitinous layer of the connecting ring was highly flexible and elastic (Weitschat \& Bandel 1991; Mutvei et al. 2012, Figure 12A, C), and resistant against diagenetic destruction. It is not known whether the connecting ring in the bactritid-like 

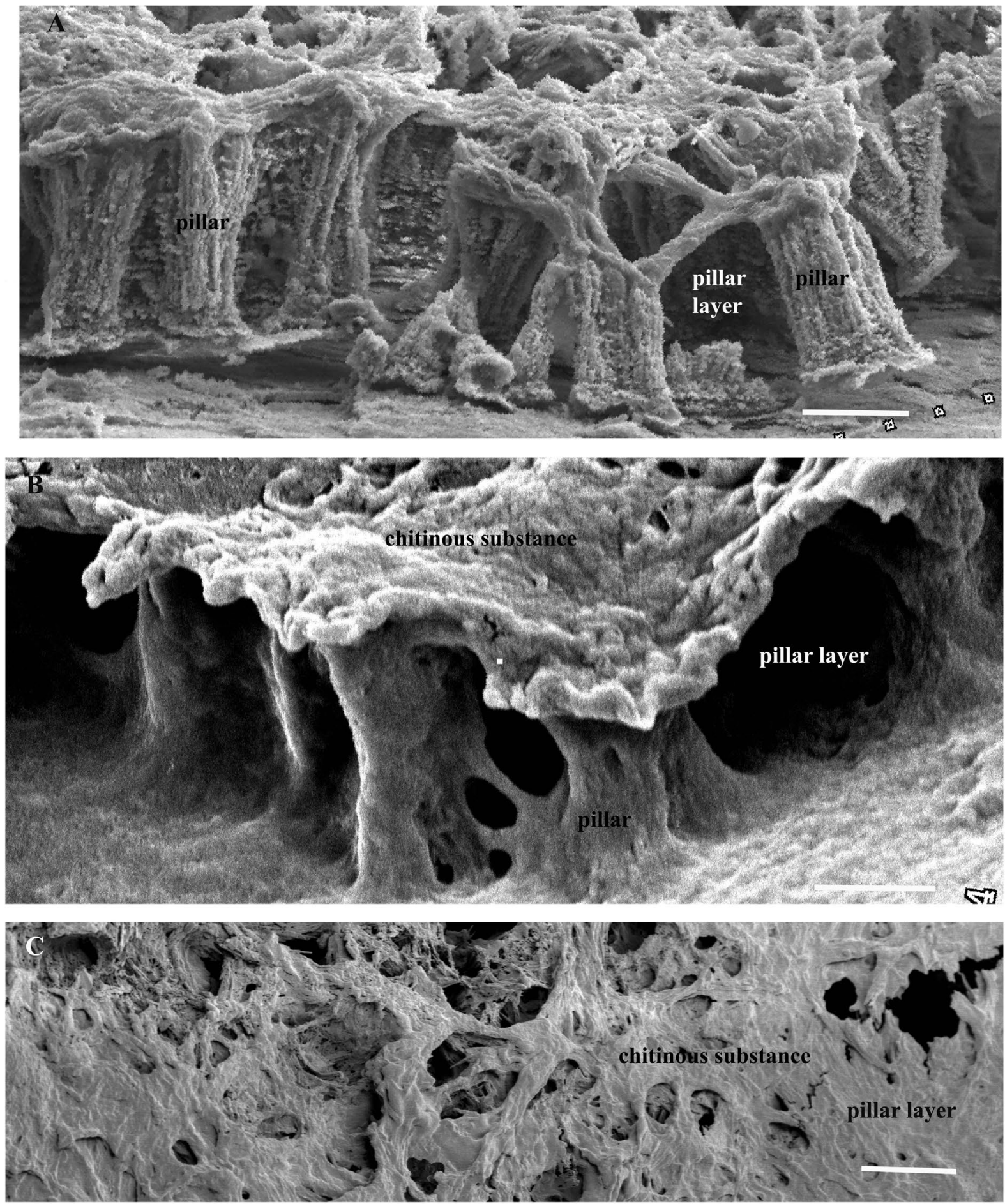

Figure 5. SEM images. Spirula. Specimens no. Mo.180832, Mo. 180833. Mo. 180834. A, B, C. Longitudinal sections of the pillar layer, treated for 15 min A, 30 min B and $1 \mathrm{~h} \mathrm{C}$ with the Mutvei's solution; note the high amount of the chitinous substance that is preserved after the dissolution of the calcareous crystals. Scale bars: $=10 \mu \mathrm{m}$.

coleoids contain minute pore canals as that in the ammonoids and ammonoids with partially endocochleate shells.

\section{Ammonoids and Ammonoids with Partially Endocochleate Shells (Figure 6E, F)}

It is still unknown how many ammonoids had their shells entirely or partially covered by living tissues. Ammonoids with shells partially covered by living tissues occurred in Ammonitina and Lytoceratina. This is indicated by: additional layers on the shell surface; abnormal sequence of the shell layers; high amount of the chitinous substance in the shell wall; ultrathin apertural margin (Doguzhaeva \& Mutvei 1993, 2015; Mutvei 2014). There are also indications that in some taxa of Goniatina and Anarcestina the shell was covered at least partially by soft tissues (summarized in Doguzhaeva \& Mutvei 2015). The connecting ring in the 


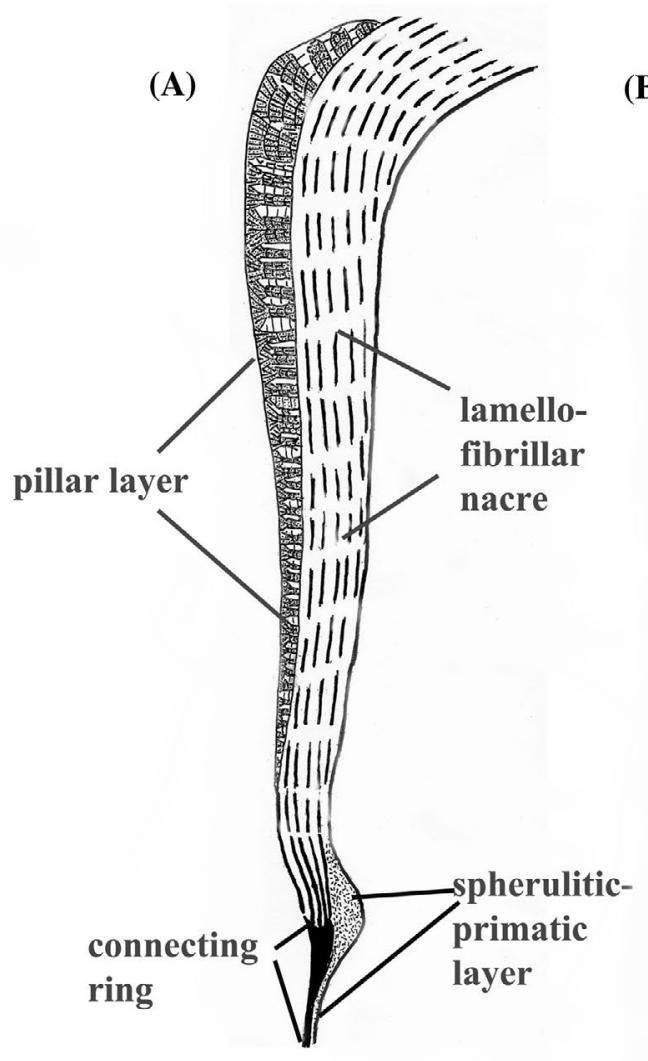

\section{Spirula}

(B)

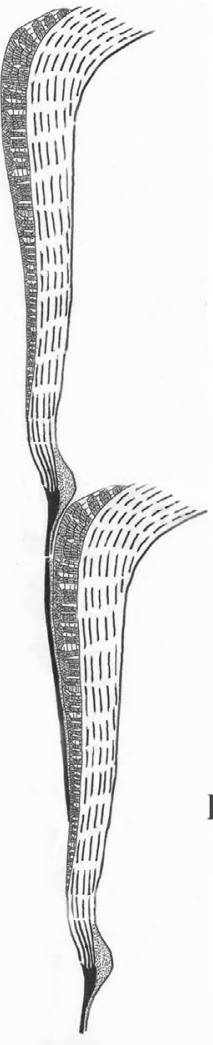

(C)
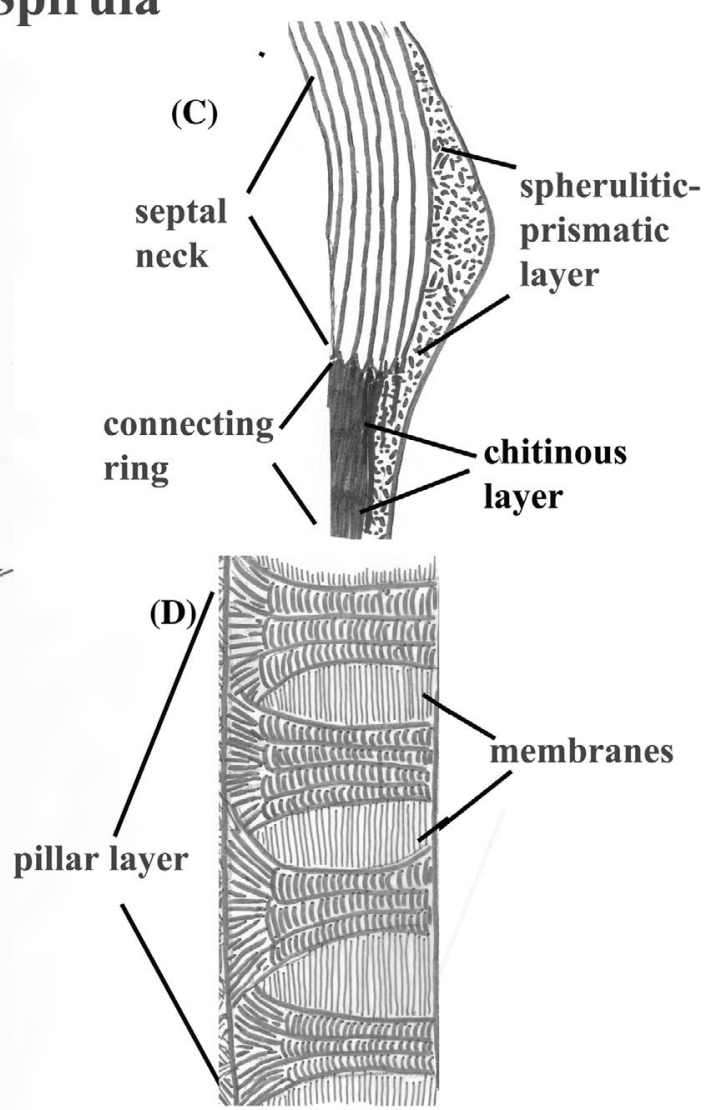

\section{Ammonoid and ammonoid-like coleoid}

\section{Bactritid-like coleoid}

(E)

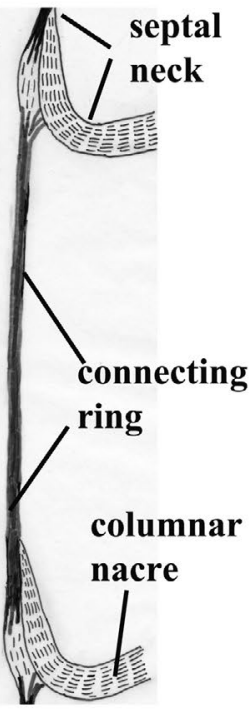

(F) pore-canals

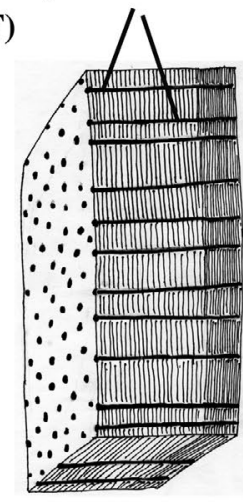

connecting ring

Figure 6. Schematic presentations. A-D. Spirula type of the siphuncle. A. Structure of the septal neck and connecting ring. B. Two consecutive siphuncular segments; note the narrow permeable passage for cameral liquid between the siphuncular segments; C. Section of the septal neck and connecting ring. D. Section of the pillar layer in higher magnification. E, F. Siphuncular type in ammonoids and ammonoids with partially endocochleate shells. E. Section of the siphuncular wall. F. Connecting ring in higher magnification; note the pore canals. G. Bactritid-like coleoid type of the siphuncle. Section of the septal neck and connecting ring.

ammonoids and ammonoids with partially endocochleate shells consists of a single chitinous layer that is traversed by numerous pore canals, ca $0.1 \mu \mathrm{m}$ in diameter (Figure 6F; Mutvei et al. 2004; Mutvei \& Dunca 2007; Doguzhaeva et al. 2010). This layer was highly flexible (Weitschat \& Bandel 1991; Mutvei unpublished observations) and resistant against diagenetic destruction. It agrees in these respects to the single chitinous layer of the connecting ring in the bactritid-like coleoids (Mutvei et al. 2012). 


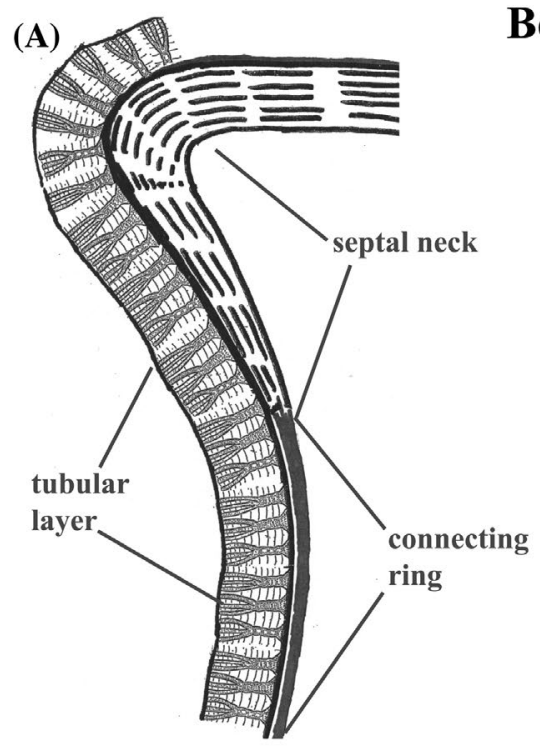

\section{Belemnitid}

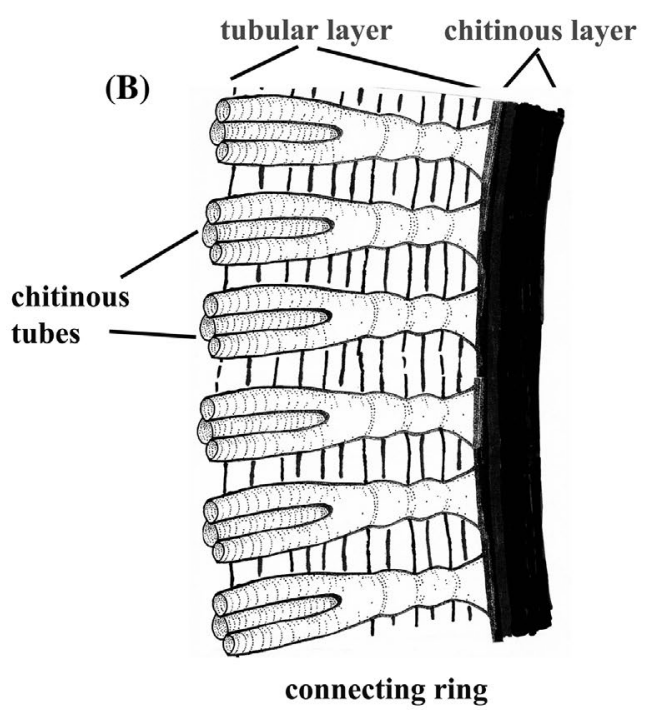

\section{Phragmoteuthid}
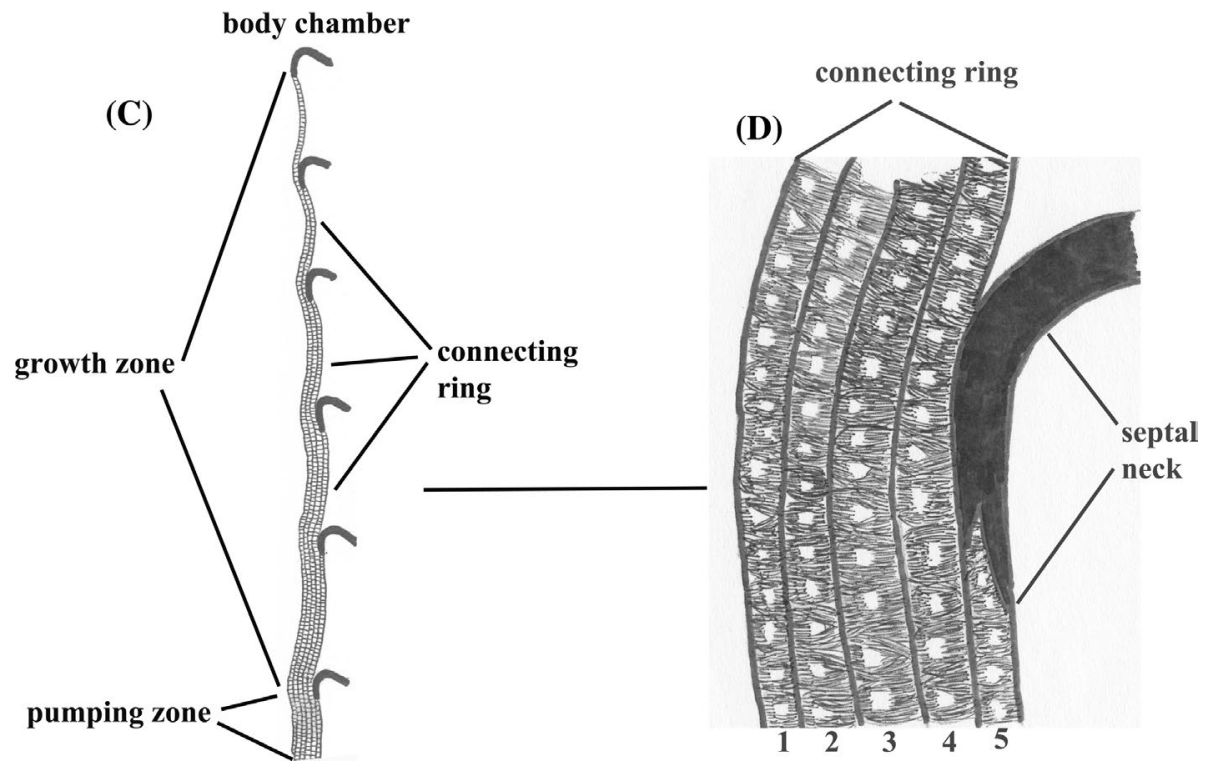

Figure 7. Schematic presentations. A, B. Belemnitid type of the siphuncle. A. Septal neck and connecting ring. B. Connecting ring in higher magnification. C, D. Phragmoteuthid type of the siphuncle. C. Adoral section of the siphuncular wall to show extremely long connecting rings in the growth zone. D. Septal neck and five connecting rings in higher magnification.

\section{Belemnitids (Figure 7A, B)}

The siphuncular structure was recently studied in the Jurassic belemnitid Megateuthis (Mutvei 2015b). In the belemnitids and in the extant Spirula, the septum and the septal neck are composed of the lamello-fibrillar nacre (Mutvei 1972). Instead of the calcareous pillar layer in Spirula, the inner surface of the septal neck in the belemnitid Megateuthis is covered by an organic tubular layer (Figure 7A). Each tube has a chitinous wall and is divided into three branches that are directed towards the siphuncular cavity (Figure 7B). The tubes probably contained epithelial extensions from the siphuncular cord. The tubular chitinous layer continues into the connecting ring where it becomes the inner layer. The outer layer of the connecting ring is a chitinous layer that emerges from the distal end of the septal neck. As in the ammonoids and

ammonoids with partially endocochleate shells, and in the bactritid-like coleoids, the spherulitic-prismatic layer of the connecting ring is not developed. The chitinious layer of the connecting ring was highly flexible and elastic and resistant against diagenesis. The connecting ring structure in the belemnitid Megateuthis is similar to that in the aulacocerid Mojsisovicsteuthis (Mutvei 1971, pl. 5). The unique and complicated siphuncular structure in belemnitids and aulacocerids is different from that in other cephalopods. 


\section{Sepia}

In the extant Sepia the chitinous, strip-like sheets cover the openings to the cuttlebone chambers, being tightly attached to the adoral surfaces of the adjacent septa (Doguzhaeva \& Mutvei 2012; Doguzhaeva \& Dunca 2015). The sheets are homologues of the connecting rings in other cephalopods. They consist of fibrous chitin and are flexible. Each sheet is probably perforated by numerous micropores (Doguzhaeva \& Mutvei 2012, figures $3,4)$, similar to those in the chitinous connecting rings in the ammonoids and ammonoids with partially endocochleate shells (Mutvei et al. 2004; Mutvei \& Dunca 2007; Doguzhaeva et al., 2010).

\section{Discussion}

The extant Spirula is the only, hitherto known coleoid in which the connecting ring consists of similar two layers as that in the fossil nautilosiphonate nautiloids and extant Nautilus: the inner chitinous layer, and the outer spherulitic-prismatic layer (Mutvei 2015a). This supports the opinion of Engeser \& Bandel (1988) that Spirula is an ancient species of recent Decabranchia. This is also supported by DNA analysis by Warnke et al. (2003)

In the bactritid-like coleoids, ammonoids and ammonoids with partially endocochleate shells, and belemnitids, the siphuncular structure is different from that in the fossil nautilosiphonates and Nautilus (Mutvei 2015a): (1) the outer spherulitic-prismatic layer is absent in the septal neck and connecting ring; (2) only the inner chitinous layer of the connecting ring is present, but it differs from that layer in the nautilosiphonates by its resistance against diagenetic destruction, and by its high elasticity and flexibility. In ammonoids and ammonoids with partially endocochleate shells this layer is perforated by numerous, minute pore canals. Also the strip-like, chitinous sheet that covers the opening to the cuttlebone chamber in the extant Sepia and corresponds to the chitinous layer in the connecting ring, seems to be perforated by similar, minute pore canals (Doguzhaeva \& Mutvei 2012). Thus, during the evolution, the siphuncles in ammonoids and different coleoid taxa underwent considerable changes that resulted in the formation of six different structural types in addition to about six structural types in nautiloids (Mutvei 2015a, 2016). At the present, it is not possible to understand why these structural types appeared, and how they participated in the osmotic pumping of the cameral liquid for buoyancy regulations.

\section{Acknowledgements}

I express my gratitude to Dr Dirk Fuchs, Hokkaido University, Sapporo, Japan, and to an anonymous reviewer for valuable constructive criticism.

\section{Disclosure statement}

No potential conflict of interest was reported by the author.

\section{References}

Appellöf, A., 1893: Die Schalen von Sepia, Spirula und Nautilus. Studien über den Bau und das Wachsthum [Shells of Sepia, Spirula and Nautilus. Studies on morphology and growth]. Kongliga svenska vetenskapsacademiens Handlingar 25, 106 pp.
Bandel, K., 1990: Cephalopod shell structure and general mechanism of shell formation. In J.G. Carter (ed.): Skeletal Biomineralization: Patterns, Processes and Evolutionary Trends, 97-115. Van Nostrand Reinhold, New York.

Bandel, K. \& Boletzky, S., 1979: A comparative study of the structure, development and morphological relationships of chambered cephalopod shells. The Veliger 21, 313-354.

Branco, W., 1880: Beiträge zur Entwicklungsgeschichte der fossilen Cephalopoda (Contribution to development of fossil cephalopods). Palaeontographica 27, 13-81.

Bruun, A.F., 1943: The biology of Spirula spirula (L.). Dana Report 24, 1-44. Checa, A.G., Cartwright, J.H.E., Sánchez-Almazo, I., Andrade, J.P. \& RuizRaya, F., 2015: The cuttlefish Sepia officinalis (Sepiidae, Cephalopoda) constructs cuttlebone from a liquid-crystal precursor. Scientific Reports 5, 11513. doi:http://dx.doi.org/10.1038/srep11513.

Clarke, M.R., 1969: Cephalopoda collected on the SOND cruise. Journal of the Marine Biological Association of the UK 49, 961-976.

Clarke, M.R., 1970: Growth and development of Spirula Spirula. Journal of the Marine Biological Association of the UK 50, 53-64.

Dauphin, Y., 1976: Microstructure des coquilles de Céphalopodes [Microstructure of cephalopod shells]. I Spirula spirula L. (Dibranchiata, Decapoda). Bulletin du Muséum National d'Histoire, Sciences de la Terre 54, 197-238.

Doguzhaeva, L.A., 2000: The evolutionary morphology of siphonal tube in Spirulida (Cephalopoda, Coleoidea). Revue de Paléobiologie Vol. Spec 8, 85-94.

Doguzhaeva, L.A. \& Mutvei, H., 1993: Structural features in Cretaceous ammonoids indicative of semi-internal or internal shells. In M.R. House (ed.): The Ammonoidea: Environment, Ecology and Evolutionary Change. The Systematics Association Special Volume 47, 99-114. Clarendon Press, Oxford.

Doguzhaeva, L.A. \& Mutvei, H., 2012: Connecting stripes: an organic skeletal structure in Sepia from Red Sea. Geobios 45, 13-17.

Doguzhaeva, L.A. \& Mutvei, H., 2015: The additional external shell layers indicative of "Ectocochleate experiments" in some Ammonoids. In C. Klug, D. Korn, K. De Baets, I. Kruta \& R.H. Mapes (eds.): Ammonoid Paleobiology: From Anatomy to Ecology, 585-609. Springer, Dordrecht Heidelberg, New York, London.

Doguzhaeva, L.A. \& Dunca, E., 2015: Siphonal zone structure in the cuttlebone of Sepia officinalis. Swiss Journal of Palaeontology 134, 167176. doi:http://dx.doi.org/10.1007/s13358-015-0085-y.

Doguzhaeva, L.A., Mapes, R.H. \& Mutvei, H., 1999: A late Carboniferous spirulid coleoid from the southern Mid-Continent (USA). In F. Oloriz \& F.J. Rodriguez-Towar (eds.): Advancing Research on Living and Fossil Cephalopods, 47-57. Kluwer Academic/Plenum Bublishers, New York.

Doguzhaeva, L.A., Mutvei, H. \& Weitschat, W., 2003: The pro-ostracum and primordial rostrum at early ontogeny of Lower Jurassic belemnites from north-western Germany. In K. Warnke, H. Keupp \& S. von Boletzky (eds.): Coleoid cephalopods through time, 79-89. Berliner Paläobiologische Abhandlungen 3, Berlin.

Doguzhaeva, L.A., Bengtson, S. \& Mutvei, H., 2010: Structural and morphological indicators of mode of life in the Aptian lytoceratid ammonoid Eogaudryceras. In K. Tanabe, Y. Shigeta, T. Sasaki \& H. Hirano (eds.): Cephalopods - Present and Past, 123-130. Tokai University Press, Tokyo.

Engeser, T. \& Bandel, K., 1988: Phylogenetic classification of coleoid cephalopods. In J. Wiedmann \& J. Kullmann (eds.): Cephalopods, Present and Past, 105-115. E. Schweitzerbart'sche Verlagbuchhandlung, Stuttgart.

Hoffmann, R. \& Warnke, K., 2014: Spirula - das unbekannte Wesen aus der Tiefsee. Denisia 32, 33-46.

Mapes, R.H., 1979: Carboniferous and Permian Bactritoidea (Cephalopoda) in North America. The University of Kansas Paleontological Contributions Article 64, 1-75.

Mutvei, H. 1964: On the shells of Nautilus and Spirula with notes on the shell secretion in non-cephalopod molluscs. Arkiv för Zoologi 16, 221-278.

Mutvei, H., 1970: Ultrastructure of the mineral and organic components of molluscan nacreous layers. Biomineralization 2, 48-61.

Mutvei, H., 1971: The siphonal tube in Jurassic Belemnitida and Aulacocerida (Cephalopoda: Coleoidea). Bulletin of the Geological Institutions of the University of Uppsala, New Series 3, 27-36. 
Mutvei, H., 1972: Ultrastructural studies on cephalopod shells. Part 1. The septa and siphonal tube in Nautilus. Bulletin of the Geological Institutions of the University of Uppsala New Series 3, 237-261.

Mutvei, H., 1997: Siphuncular structure in Ordovician endocerid cephalopods. Acta Palaeontologica Polonica 42, 375-390.

Mutvei, H., 2014: Shell wall structure and sharp-edged apertural shell margin in the Callovian Quenstedtoceras (Cephalopoda, Ammonoidea). GFF 136, 531-538.

Mutvei, H., 2015a: Characterization of two new superorders Nautilosiphonata and Calciosiphonata and a new order Cyrtocerinida of the subclass Nautiloidea; siphuncular structure in the Ordovician nautiloid Bathmoceras (Cephalopoda). GFF 137(3), 164-174. doi:http://dx.doi. org/10.1080/11035897.2015.1061592.

Mutvei, H., 2015b: Siphuncular structure in Jurassic belemnitid Megateuthis (Cephalopoda: Coleoidea). GFF 137(1), 66-73. doi:http://dx.doi.org/ 10.1080/11035897.2014.962077.

Mutvei, H., 2016: Siphuncular structures in Calciosiphonate nautiloid orders Actinocerida, Orthocerida and Barrandeocerida (Cephalopoda), GFF 137, 164-174. doi:http://dx.doi.org/10.1080/11035897.2015. 1123768.

Mutvei, H. \& Donovan, D.T., 2006: Siphuncular structure in some fossil coleoids and recent spirula. Palaeontology 49, 685-691.

Mutvei, H. \& Dunca, E., 2007: Connecting ring ultrastructure in the Jurassic ammonoid Quenstedtoceras with discussion on mode of life of ammonoids. In R.H. Landman, R.A. Davis \& R.H. Mapes (eds.): Sixth International Symposium Cephalopods Present and Past. New Insights and Fresh Perspectives, 239-256. Springer, Dordrecht.

Mutvei, H., Mapes, R.H. \& Doguzhaeva, L.A., 2012: Shell structures in Carboniferous bactritid-like coleoids (Cephalopoda) from South Central USA. GFF 134, 201-216.

Mutvei, H., Weitschat, W., Doguzhaeva, L.A. \& Dunca, E., 2004: Connecting ring with pore canals in two genera of Mesozoic ammonoids. Mitteilungen von Paläontologisches Institut der Universität Hamburg 688, 135-144.

Schöne, B.R., Dunca, E., Fiebig, J. \& Pfeiffer, M., 2005: Mutvei's solution: an ideal agent for resolving microgrowth structures of biogenic carbonates. Palaeogeography, Palaeoclimatology, Palaeoecology 228, 149-166.

Warnke, K.M., Oppelt, A. \& Hoffmann, R., 2010: Stable isotopes during ontogeny of Spirula and derived hatching temperatures. Ferrantia 59, 191-201.

Warnke, K.M., Plötner, J., Santana, J.I., Rueda, M.J \& Llinás, O., 2003: Reflections on the phylogenetic position of Spirula (Cephalopoda): Preliminary evidence from the $18 \mathrm{~S}$ ribosomal RNA Gene. In K. Warnke, H. Keupp \& S. von Boletzky (eds): Coleoid Cephalopods Through Time, 253-260. Berliner Paläobiologische Abhandlungern Band 3, Berlin.

Weitschat, W. \& Bändel, K., 1991: Organic components in phragmocones of boreal triassic ammonoids: Implications for ammonoid biology. Paläontologische Zeitschrift 65, 269-303. 